PUBLIKAUMA: Jurnal Ilmu Administrasi Publik UMA, 9 (2) (2021): 71-80

DOI: http://dx.doi.org/10.31289/publika.v9i2.6027

PUBLIKAUMA: Jurnal Ilmu Administrasi Publik

Available online http://ojs.uma.ac.id/index.php/publikauma

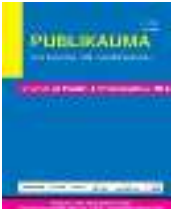

\title{
Implementasi Kebijakan Pemerintah dalam Meningkatkan Kualitas Pendidikan di Aceh Barat
}

\section{Implementation of Government Policies in Improving the Quality of Education in West Aceh}

\author{
Safrida ${ }^{1}$, Nila Safrida ${ }^{2}$, Muhammad ${ }^{3}$ \\ 1,2,3 Fakultas Ilmu Sosial \& Ilmu Politik, Universitas Teuku Umar, Indonesia
}

Disetujui: Nopember 2021; Direview: Nopember 2021;Diterima: Desember 2021

\section{Abstrak}

Penelitian ini memiliki tujuan untuk menganalisis implementasi kebijakan pemerintah dalam meningkatkan kualitas pendidikan di Aceh Barat, disertai penguraian upaya implementasi dan kendala dalam pelaksanaan kebijakan. Metode yang peneliti gunakan adalah kualitatif dengan pendekatan studi kasus, sumber data penelitian berasal dari wawancara dengan teknik purposive, observasi dan studi literatur. Tahapan analisi data menggunakan model analisis interaktif. Hasil penelitian menunjukkan jika dalam implementasi kebijakan peningkatan kualitas pendidikan di Aceh Barat belum menunjukkan hasil maksimal, akibat ketebatasan anggaran pelaksanaan program, masih minimnya kerjasama antara dinas pendidikan dan masyarakat, terdapat banyak lembaga pendidikan tapi tidak di ikuti kuantitas siswa yang cukup dan minim serta terbatasnya kualitas maupun kuantitas pengajar di lokasi terpencil. Maka, dapat disimpulkan bahwa implementasi kebijakan dalam meningkatkan kualitas pendidikan di Aceh Barat telah dilaksanakan dengan cukup baik, meski menghadapi berbagai masalah atau kendala dalam pelaksanaannya, sehingga diperlukan keseriusan dari pemerintah dan semua pihak untuk dapat bergerak bersama meningkatkan kualitas pendidikan di Aceh Barat.

Kata Kunci: Perbandingan, Kinerja, Pembangunan Manusia, Sosial Ekonomi

\begin{abstract}
This study intends to examine the implementation of government policies aimed at enhancing the quality of education in Aceh Barat, as well as the efforts and restrictions involved in doing so. The research method is qualitative with a case study approach, and the data for the study comes from purposive interviews, observations, and literature reviews. An interactive data analysis model is used to go through the stages of data analysis. The study's findings show that budget constraints for program implementation, a lack of cooperation between the education office and the community, a large number of educational institutions but a small number of students, and limited quality and quantity of locations in remote areas have all hampered the implementation of policies to improve the quality of education in West Aceh.
\end{abstract}

Keywords: Management, Community Driven Development

How to Cite : Safrida, Safrida, N\& Muhammad . (2021). Implementasi Kebijakan Pemerintah dalam Meningkatkan Kualitas Pendidikan di Aceh Barat. PUBLIKAUMA: Jurnal Ilmu Administrasi Publik UMA, Vol. 9 (2): 71-80

*Corresponding author:

ISSN 2549-1660 (Print)

E-mail: safridanila@gmail.com

ISSN 2580-2011 (Online) 


\section{PENDAHULUAN}

Pendidikan merupakan unsur terpenting dalam meningkatkan dan memperbaiki kualitas hidup masyarakat serta menjadi kunci utama dalam perbaikan kualitas sumber daya manusia, sehingga suatu pendidikan haruslah berkualitas. Kualitas pendidikan ialah kondisi dimana segala sistem pendidikan diupayakan dan diarahkan secara efektif demi meningkatkan nilai faktor input pendidikan untuk melahirkan hasil ouput yang lebih maksimal (Sagala, 2009).

Bagi negara Indonesia, pendidikan merupakan hal yang sangat bernilai, sebab telah termaktub dalam pembukaan UUD 1945 alenia 4 bahwa tujuan dari berdirinya negara Indonesia adalah untuk mencerdaskan kehidupan bangsa, sehingga negara bertanggung jawab dan memiliki kewajiban menciptakan masyarakat yang cerdas melalui pendidikan berkualitas.

Berpegangan pada tujuan tersebut, berbagai regulasi aturan mengenai penguatan pendidikan Indonesia dikeluarkan. Sebut saja UU No 20 Tahun 2003 Tentang Sistem Pendidikan Nasional, PP No 32 Tahun 2013 Tentang Standar Nasional Pendidikan, hingga penerbitan Peraturan Pemerintah No 57 Tahun 2021 Tentang Standar Pendidikan Nasional, yang menjadi pedoman pendidikan Indonesia. Pelaksanaan regulasi tersebut diharapkan dapat menciptakan kesesuaian antara sistem pendidikan dengan dinamika dan perkembangan IPTEK untuk kepentingan penaikan mutu pendidikan (Pemerintah Pusat, 2021)

Upaya peningkatan kualitas pendidikan berdasarkan regulasi yang disebutkan sebelumnya merupakan manifestasi UUD 1945 pasal 31 ayat 1 dan 3 (Pemerintah Pusat, 1949), yang telah dilakukan sejak lama, namun nyatanya belum memberikan hasil signifikan bagi peningkatan kualitas pendidikan di Indonesia. Hal ini dibuktikan oleh data dari International Student Assessment (PISA) mengenai pengetahuan murid dalam matematika, membaca dan ilmu pendidikan yang menyebutkan jika Indonesia masuk dalam 10 negara dengan tingkat pendidikan terendah berada di peringkat ke 72, tertinggal dari (56) dan Brunai Darussalam (59) dengan negara China sebagai pemegang peringkat puncak (1) (BBC.com, 2019).

Tabel 1. 10 Negara dengan Peringkat Kualitas Pendidikan Terendah

\begin{tabular}{lll}
\hline No & Nama Negara & Peringkat \\
\hline 1 & Azerbaijan & 68 \\
\hline 2 & Kazakhstan & 69 \\
\hline 3 & Georgia & 70 \\
\hline 4 & Panama & 71 \\
\hline 5 & Indonesia & 72 \\
\hline 6 & Morocco & 73 \\
\hline 7 & Lebanon & 74 \\
\hline 8 & Kosovo & 75 \\
\hline 9 & Dominican Republic & 76 \\
\hline 10 & Philippines & 77 \\
\hline \multicolumn{3}{c}{ Sumber: Data PISA 2018 (BBC.com, 2019). }
\end{tabular}

Rendahnya peringkat Indonesia bukan tanpa sebab. Menurut (Budiharto et al., 2018) rendahnya pendidikan Indonesia dikarenakan adanya dualisme peran dari Depdiknas dan Departemen Agama sehingga berakibat pada ambigunya distrubusi tanggung jawab, manajerial, dan terpilahnya sistem pembiayaan program pendidikan, serta terjadi perebutan kewenangan guru. Di samping itu, kesenjangan kondisi sosial ekonomi antar daerah juga menjadi pemicu timpangnya pendidikan satu daerah dibanding daerah lain, sehingga secara langsung mempengaruhi kualitas pendidikan antar darah pada skala nasional.

Kesenjangan tersebut menjadi cerminan ketertinggalan Indonesia dibanding negara lain, yang haruslah dikejar agar Indonesia tak kalah saing, terutama dalam ranah pasar tenaga kerja. Maka dari itu, kerjasama Pemerintah Pusat dengan daerah di Indonesia diperlukan untuk memutar balik posisi ini melalui implementasi secara maksimal regulasi aturan pendidikan yang dikeluarkan. Sayangnya dalam gencarnya usaha pemerintah memperbaiki kualitas pendidikan negara, pandemi Covid-19 menerpa sehingga mengakibatkan berbagai regulasi aturan pemerintah tidak bisa dilaksanakan dengan semestinya, dan harus beradaptasi, baik dari segi anggaran maupun adaptasi kebiasaan baru yang secara tidak langsung mengubah arah pelaksanaan program. 
Pembahasan mengenai upaya perbaikan pendidikan Indonesia telah dijabarkan dalam beberapa penelitian sebelumnya. Berdasarkan penelitian yang dilakukan (Saputra et al., 2015), menyebutkan jika kemiskinan juga menjadi pemicu rendahnya kualitas pendidikan di suatu daerah. Selaras dengan pernyataan tersebut, (Fadhilah \& Syahril, 2019) juga menyatakan pembinaan pendidikan di sekolah, dan mengupayakan pelaksanaan peningkatan mutu pendidikan mejadi solusi perbaikan kualitas pendidikan. Perbaikan tersebut dapat dilakukan melalui pelaksanaan pelatihan bagi pengawas pelaksaaan pendidikan hingga pelatihan manajerial berbasis sekolah dalam upaya memperbaiki kualitas pendidikan.

Selain itu, kesadaran akan pentingnya pendidikan juga menjadi alasan rendahnya kualitas pendidikan, sebagaimana hasil penelitian (Suparno \& Alfikar, 2019), yang menjelaskan rendahnya kesadaran pendidikan pada masyarakat masih menjadi masalah dalam implementasi UUD 1945 Pasal 31 ayat 1 , ditandai dengan rendahnya pemahaman orang tua akan pentingnya pendidikan. Oleh sebab itu, pemberian bantuan biaya sekolah, pemberian motivasi, dorongan serta penguatan agar anak bersekolah adalah sesuatu yang benar-benar penting.

Selama ini penelitian tentang kualitas pendidikan kebanyakan hanya menilai dari segi pandangan masyarakat sebagai kelompok yang terdampak dari kebijakan pendidikan pemerintah, akan tetapi dalam penelitian ini, peneliti akan mencoba memperdalam realita implementasi kebijakan pemerintah dibidang pendidikan dari sudut pandang pemerintah itu sendiri yaitu Dinas Pendidikan Kabupaten, sehingga hasil penelitian nantinya akan memberi uraian berbeda dengan penelitian sebelumnya berupa fakta upaya yang dilakukan pemerintah kabupaten dalam memperbaiki kualitas pendidikan di lokasi penelitian.

Penelitian ini memakai teori George C. Edward III sebagai alat analisis, diikuti penjabaran empat indikator yang mempengaruhi implementasi suatu kebijakan yaitu komunikasi, sumber daya, disposisi dan struktur birokrasi (Edward. III, 1980). Teori ini dipilih karena dapat menguraikan dengan sistematis realita implementasi suatu kebijakan dan memperlihatkan penghambat implementasi kebijakan tersebut. Penelitian akan dilaksanakan di Kabupaten Aceh Barat yang merupakan bagian dari provinsi Aceh.

Secara umum Provinsi Aceh telah dikenal sebagai provinsi termiskin di Sumatera, dan pada tahun 2019 Aceh juga dikategorikan Provinsi dengan kualitas pendidikan rendah, menempati posisi 27 dari 34 provinsi (Zairi, 2019). Padahal Aceh dikenal sebagai daerah otonomi khusus yang telah dibekali dana pendidikan oleh pemerintah maupun dari hak otonomi khusus yang dimiliki demi meningkatkan kualitas pendidikan (Saputra et al., 2015). Melihat realita tersebut, menjadi menarik bagi kita untuk mengetahui penerapan regulasi peraturan nasional di Aceh, terutama UUD 1945 Pasal 31 ayat 1 dan 3. Pelaksanaan regulasi aturan dasar tersebut telah didukung berbagai peraturan daerah, salah satunya Qanun No 32 Tahun 2018 Tentang Penyelenggaraan Pendidikan Dayah sebagai regulasi khusus peraturan pendidikan di Aceh (Pemeritah Aceh, 2018). Kebijakan tersebut bukan hanya dilaksanakan oleh pemerintah daerah dalam lingkup provinsi saja, tetapi juga pemerintah kabupaten seperti Dinas Pendidikan kabupaten Aceh Barat.

Maka dari itu, tujuan dari penelitian ini adalah melihat realita implementasi kebijakan peningkatan kuaitas pendidikan di Aceh Barat dari segi penerapan UUD 1945 Pasal 31 Tentang Pendidikan dan Kebudayaan pada Ayat 1 dan 3, diikuti penjabaran berbagai upaya yang dilakukan Dinas Pendidikan kabupaten Aceh Barat dalam menerapkan kebijakan, disertai uraian kendala saat implementasi kebijakan dilakukan. Oleh karena itu, peneliti merasa tertarik untuk meneliti tentang Implementasi Kebijakan Pemerintah dalam Meningkatkan Kualitas Pendidikan di Aceh Barat.

\section{METODE PENELITIAN}

Penelitian ini dilakukan di Kabupaten Aceh Barat, tepatnya pada Dinas Pendidikan Kabupaten Aceh Barat, dengan melibatkan staf kedinasan sebagai informan. Metode penelitian yang digunakan adalah metode kualitatif dengan pendekatan studi kasus. 
Pendekatan studi kasus dipilih karena penelitian memerlukan analisis cermat mengenai suatu program, peristiwa, maupun kelompok individu (Creswell, 2010). Data dalam penelitian ini berupa data primer yang berasal dari hasil wawancara dan observasi melibatkan staf Dinas Pendidikan kabupaten Aceh Barat, dan data sekunder bersumber dari studi literatur e-jurnal, e-book, aturan, hingga dokumen pemerintahan.

Teknik analisis data yang digunakan adalah model analisis interaktif, sesuai pandangan Miles dan Huberman dalam (Moleong, 2017), yang meyebutkan tahapan analisis data terdiri dari koleksi data, reduksi data, penyajian data, serta verifikasi dan penarikan kesimpulan.

Penentuan narasumber atau informan penelitian sebagai sumber data primer ditetapkan melalui teknik purposive sampling (menurut kriteria tertentu) meliputi:

Tabel 2. Identitas Informan

\begin{tabular}{|c|c|c|}
\hline Nama & Jabatan & Instansi \\
\hline Muhammad & Kabid & Dinas \\
\hline \multirow{3}{*}{ Nasir, S.Pd } & Pendidikan & Pendidikan \\
\hline & Dasar & Kabupaten \\
\hline & & Aceh Barat \\
\hline \multirow[t]{4}{*}{ Arnawita, A,md } & Operator & Dinas \\
\hline & Bidang & Pendidikan \\
\hline & Pendidikan & Kabupaten \\
\hline & Dasar & Aceh Barat \\
\hline \multirow[t]{4}{*}{ Erianis } & Korwil 2 Aceh & Dinas \\
\hline & Barat & Pendidikan \\
\hline & & Kabupaten \\
\hline & & Aceh Barat \\
\hline \multirow{2}{*}{$\begin{array}{l}\text { H. Cut Aswadi, } \\
\text { S.Ag., M.Pd }\end{array}$} & Kepala & MAN 1 Aceh \\
\hline & Sekolah & Barat \\
\hline \multirow{3}{*}{ Nur Asma } & Masyarakat & - \\
\hline & Kota & \\
\hline & Meulaboh & \\
\hline
\end{tabular}

\section{HASIL DAN PEMBAHASAN}

Kabupaten Aceh Barat merupakan salah satu kabupaten di Aceh yang masih menghadapi masalah di bidang pendidikan, dengan jumlah siswa umur 4 sampai 19 Tahun yang mencapai 33.478 orang, dan total lembaga pendidikan SD berjumlah 158 SD dan 68 SMP (BPS Kab Aceh Barat, 2021). Berdasarkan hasil observasi, peneliti masih kerap menjumpai siswa yang buta huruf di wilayah yang berlokasi sedikit lebih jauh dari perkotaan, diikuti fasilitas dan sarana pendidikan yang minim. Padahal kita telah tahu apabila pemerintah pusat telah menganggarkan $20 \%$ pendapatan dari APBN dan APBD untuk meningkatkan serta memajukan mutu pendidikan, dibarengi penyediaan beasiswa (Inkiriwang, 2020)

Dinas Pendidikan Kabupaten Aceh Barat adalah salah satu kedinasan yang memiliki peran penting dalam proses implementasi kebijakan pendidikan di Aceh Barat, termasuk dalam peningkatan kualitas atau mutu pendidikan. Keberadaan Dinas Pendidikan Aceh Barat telah dipelopori Qanun Aceh Barat No 9 Tahun 2018 Tentang Pembentukan Susunan Perangkat Daerah Kabupaten Aceh Barat (Pemerintah Aceh Barat, 2018). Kontribusi pemerintah dalam implementasi kebijakan adalah kewajiban, sebab pemerintah merupakan perantara bagi masyarakat untuk mendapatkan berbagai akses yang telah diatur dalam kebijakan.

Implementasi kebijakan menurut (Mulyadi, 2015), ialah tindakan yang mengacu pada upaya mencapai tujuan-tujuan yang telah ditetapkan dalam suatu keputusan sebelumnya. Berbicara tentang pendidikan, Aceh Barat sebagai Kabupaten yang memiliki 12 Kecamatan dengan total 68 SMP dan 158 SD berada di bawah naungan Dinas Pendidikan Aceh Barat menjadi tolak ukur bagi pemerintah kabupaten untuk memaksimalkan program pendidikan demi mengoptimalkan kualitas pendidikan yang diterima siswa secara berkeadilan. Sebagaimana amanat Undang-Undang Dasar 1945 pasal 31 ayat (1) dimana "Setiap warga negara berhak mendapatkan pendidikan" dan (3), "Pemerintah mengusahakan dan menyelenggarakan satu sistem pendidikan nasional yang meningkatkan keimanan dan ketakwaan serta akhlak mulia dalam rangka mencerdaskan kehidupan bangsa yang merupakan salah satu tujuan dari Negara Indonesia" sehingga tanggungjawab ini menjadi hal yang di emban Dinas Pendidikan kabupaten melalui implementasi kebijakannya.

\section{Implementasi Kebijakan Peningkatan Kualitas Pendidikan}

Implementasi adalah tahap penting dalam proses kebijakan sebab menjadi 
tahapan yang berfungsi mentransmisikan aturan pemerintah pada target group atau masyarat. Implementasi juga dapat dimaknai sebagai suatu tahapan pada proses kebijakan publik setelah tahapan perumusan kebijakan dengan maksud tujuan yang jelas, dalam jangka waktu pelaksanaan jangka pendek, menengah hingga jangka panjang. Menurut Solichin dalam (Solichin, 2015), kebijakan merupakan bentuk kekuasaan dari negara melalui pembatasan kepentingan atas individu dengan mempertimbangkan keamanan, kesehatan, dan moral atau kesejateraan masyarakat..

Saat ini priortas pendidikan pemerintah kabuoaten ditekankan pada perbaikan karakter, seperti ungkapan H. Cut Aswadi, S.Ag., M.Pd:

"Kita disini kalau pendidikan yang paling ditekankan pada perbaikan karakter. Oleh sebab itu lembaga pendidikan sendiri menjadi pihak yang snagat mendukung program pendidikan karakter dari pemerintah" (Wawancara, 14 Mei 2021)

Dari penjabaran hasil wawancara tersebut, dapat memperlihatkan jika implementasi program pendidikan di Kabupaten Aceh Barat termasuk lingkup SMA atau sederajat tetap menjadikan pendidikan karakter sebagai perbaikan utama, sehingga dalam hal ini keterlibatan Dinas Pendidikan Kabupaten Aceh Barat juga sangat penting untuk pendidikan karakter siswa SD-SMP.

Dinas Pendidikan Kabupaten Aceh Barat tentunya menjadi pihak yang bertanggung jawab dalam implementasi penyelengagaran pendidikan siswa PAUD, TK, SD dan SMP di Aceh Barat telah melakukan srategi pembangunan pendidikan, diantaranya menjalankan strategi pembangunan pendidikan nasional sesuai UU No 20 Tahun 2003 Tentang Sistem Pendidikan Nasional (Pemerintah pusat, 2003), yang meliputi kegiatan:

1. Pelaksanaan pendidikan akhlak mulia dan pendidikan agama

2. Mengembangkan kurikulum berbasis kompetensi dan melaksanakannya

3. Melakukan proses pembelajaran dialogis dan mendidik
4. Melaksanakan akreditasi, sertifikasi dan evaluasi pendidikan yang bersifat memberdayakan

5. Peningkatan profesionalitas tenaga pendidik dan pendidikan

6. Penyediaan fasilitas pembelajaran yang mendidik

7. Membiayai pendidikan yang sesuai dengan prinsip keadilan dan pemerataan

8. Penyelenggaraan pendidikan yang merata dan terbuka

9. Pelaksanaan wajib belajar

10.Pelaksanaan manajemen pendidikan se cara otonom

11.Pemberdayaan peran dari masyarakat

12.Bekerjasama dengan pusat pembangunan dan budaya masyarakat

13.Pelaksanaan pengawasan pada sistem pendidikan nasional

Berpegang pada Qanun Aceh No 5 Tahun 2008 Tentang Penyelenggaraan Pendidikan (Pemerintah Aceh, 2008), terdapat tiga urusan kebijakan pendidikan yang membagi tugas dari kelembagaan pemerintah dalam menjalankan pendidikan, pembagian tugas tersebut melingkupi:

a. Dinas Pendidikan Provinsi berwenang untuk mengelola SMA, SMK, dan SLTP

b. Dinas Pendidikan kabupaten/kota berwenang untuk mengelola TK, PAUD, SD, SMP, dan Keseteraan

c. Dinas kementerian agama berwenang mengelola MA, MI, dan MTS.

Hal ini membuktikan jika tidak semua kewenangan mengatur pendidikan kabupaten merupakan milik dari Dinas Pendidikan kabupaten, sebab terdapat jenjang yang membagi tugas dari masing-masing organisasi pemerintah dalam menyukseskan program pendidikan di Indonesia. Maka, apabila terdapat masalah pendidikan pada lingkup kabupaten, Dinas Pendidikan provinsi serta Kementerian Agama memiliki kontribusi, namun peran dari Dinas Pendidikan Kabupaten menjadi sangat penting sebab berwenang mengelola lebih banyak lembaga pendidikan kabupaten dibanding dua instansi lainnya.

Demi melihat keberhasilan implementasi kebijakan pemerintah dalam meningkatkan 
kualitas pendidikan yang merujuk pada UUD 1945 pasal 1 atau 1 dan 3 di Kabupaten Aceh Barat dapat diuraikan melalui penggunaan teori implementasi kebijakan Edward III, yaitu:

Pertama, komunikasi, dalam penyelenggaraan kebijakan pendidikan, Dinas Pendidikan telah menerapkan indikator ini dengan cukup baik, tercermin dari pemahaman mumpuni yang dimiliki staf akan tugas dan fungsi masing-masing, sehingga menunjukkan jika proses komunikasi dari atasan ke bawahan atau top down hingga buttom up berhasil dilaksanakaan. Masalah yang dialami pada indikator ini adalah komunikasi yang tidak maksimal dari pihak dinas kepada masyarakat berupa sosialisasi program kebijakan dinas maupun aturan pendidikan, sehingga saat terjadi pelanggaran pada praktik kebijakan lembaga pendidikan di lapangan, seperti yang dikatakan Muhammad Nasir, S.Pd sekalu Kabid Didkdas:

"Secara umum pendidikan di Aceh Barat sudah gratis tetapi masih ada isu-isu sekolah negeri masih bayar SPP, jika ada maka harus dilaporkan" (Wawancara ,12 Mei 20210).

Hal membuktikan apabila masih terdapat sekolah negeri yang mewajibkan Sumbangan Pembinaan Pendidikan (SPP) padahal tersebut tidak dibenarkan secara hukum, akan tetapi masyarakat masih melakukan pembayaran SPP akibat minimnya pengetahuan akan hal tersebut dikarenakan minimnya sosialisasi. Sejalan dengan temuan di lokasi penelitian, (Syani et al., 2017) juga membenarkan apabila aspek komunikasi dalam implementasi kebijakan adalah sosialisasi yang dilaksanakan oleh implementor kebijakan secara berkala agar kebijakan dapat tersalurkan dengan baik.

Kedua, sumber daya, dalam proses pelaksanaan kebijakan tentu diperlukan sumber daya, baik sumber daya alam maupun manusia, hingga sumber daya lainnya seperi anggaran atau finansial berupa dana yang menjadi residu dalam pelaksanaan program. Terkait sumber daya manusia, Dinas Pendidikan membenarkan jika terdapat kendala terkait sumber daya manusia, dimana dalam penyelenggaraan pendidikan,
Pemerintah Aceh Barat kekurangan tenaga ahli dalam menjalankan program peningkatan kualitas pendidikan, seperti kekurangan pengajar pada lembaga pendidikan di daerah terpencil, seperti yang disampaikan Erianis:

"Ada kebijakan pemerintah tentang bantuan guru untuk daerah terpencil tetapi itu belum juga maksimal, dari pihak dinas sudah sering berdikusi untuk memanfaatkan dana anggaran 20\% dari APBN. Namun dana tersebut tidak bisa digunakan sepenuhnya oleh Dinas Pendidikan Kabupaten Aceh Barat, sebab dana tersebut juga milik pihak lain seperti Kementerian Agama" (Wawancara 11 Mei 2021).

Hal tersebutlah yang menjadi sebab tidak merata dan maksimalnya distribusi pendidikan Kabupaten Aceh Barat. Mengenai sumber daya dana, terutama yang berasal dari otonomi khusus. Perlu diluruskan jika berdasarkan hasil penelitian didapatkan penjelasan, bahwa dana otonomi khusus bagi pendidikan kabupaten tidak seutuhnya diperuntukan bagi program Dinas Pendidikan Kabupaten Aceh Barat, tetapi terdapat pembagian dengan instansi lain.

Dana tersebut hanya khusus digunakan oleh pihak Disdik Aceh Barat untuk biaya operasional, gaji guru dan lain sebagainya. Dampak dari pembagian ini ialah menjadikan dana yang di terima Dinas Pendidikan Kabupaten menjadi lebih sedikit meski semulanya besar. Hal ini berbeda dengan yang ditemukan oleh (Budiratna \& Qibthiyyah, 2020) dimana tinggi atau rendahnya dana otsus bahkan tidak berpengaruh secara signifikan terhadap partisipasi pendidikan di Aceh, sebab penggunaan dana otsus bidang pendidikan hanya di fokuskan pada pembangunan infratruktur fisik.

Berdasarkan hasil penelitian sebagian besar dana yang disalurkan pada Dinas Pendidikan Kabupaten, banyak terpakai untuk menanggung hak dari pegawai, seperti gaji guru/pegawai, tunjangan, pelatihan dan lain sebagainya. Sebagaimana yang dikatakan Erianis:

"Kita banyak mengahabiskan lebih besar biaya untuk gaji guru, tunjangan, biaya operasional dan lain-lain, sehingga 
untuk program hanya tersisa 700 juta ke bawah. Jika kita buat program pelatihan untuk guru atau program program hanya bisa untuk 7 kali kegiatan, sehingga 100 juta untuk untuk 3 hari atau satu kegiatan itu dananya sangat sedikit" (Wawancara, 11 Mei 21).

Banyaknya penggunaan anggaran yang terpakai bagi untuk gaji dan tunjangan pegawai, selaras dengan pendapat (Farida et al., 2021) jika budaya organisasi dan etos kerja berpatokan pada pendapatan pegawai, sehingga dua hal ini sangat mempengaruhi kinerja karyawan. Akibatnya dana bagi pelaksanaan program peningkatan kualitas pendidikan adalah sisa dari penggunaan dana sebelumnya dengan anggaran terbatas.

Perlu diketahui juga ketertinggalan Aceh di bidang pendidikan juga disebabkan kurang optimalnya fasilitas yang tersedia, dimana pihak informan Muhammad Nasir, S.Pd menyebutkan:

"Aceh mengalami musibah sejak terjadinya komplik GAM hingga tsunami. Banyak infrastruktur yang hancur, saat ini kita sedang membangun kembali semua itu atau rehabilitasi, termasuk dalam pengadaan guru, instansi-instansi dan lembaga pendidikan. Jadi, kita jangan melihat Aceh di kondisi hari ini kenapa kita jauh tertinggal karena sejarah tersebut tidak bisa kita pisahkan dari kondisi Aceh hari" (Wawancara, 12 Mei 2021).

Pernyataan di atas jelas mengisyaratkan musibah dan konflik GAM berdampak pada tingginya kebutuhan akan dana dari pemerintah untuk membangun kembali atau rehabilitasi kondisi maupun fasilitas melalui pengadaan guru, pembangunan infrastruktur lainnya, sehingga kondisi ketertinggalan pendidikan dan fasilitas saat ini merupakan dampak dari kondisi masa lalu. Selaras dengan pernyataan tersebut, jika konflik berkepanjangan mengakibatkan rendahnya SDM di Aceh, sehingga masih dibutuhkan progrm strategis untuk meningkatkan pembangunan pendidikan terkhusus pada perbaikan kualitas pendidik (Amin, 2018)
Ketiga, disposisi. Mengenai disposisi atau sikap dari implementor dalam menjalankan kebijakan pada staf Dinas Pendidikan Aceh Barat terkategori baik, dengan melakukan berbagai perbaikan pendidikan terkait penyelenggaraan pengawasan, pelaksanaan kompetisi/ olimpiade untuk meningkatkan partisipasi dan kemampuan siswa Aceh Barat. Namun, sikap kerjasama antara Dinas Pendidikan dan masyarakat masih tergolong minim. Seringkali ada berbagai program pendidikan dari dinas pemerintah yang bisa mambantu pendidikan siswa seperti program beasiswa maupun bantuan lainnya, tetapi sikap kerjasama dengan masyarakat tidak terjalin dengan baik, sehingga programprogram tersebut tidak tersalur dan tersosialisasikan secara optimal.

Keempat, struktur birokrasi. Struktur birokrasi berkenaan dengan SOP dan fragmentasi pembagian tugas pada organisasi implementor atau lembaga lain yang ikut melaksanakan kebijakan. Berdasarkan hasil penelitian, ditemukan jika fragmentasi pada struktur birokrasi terjadi, dimana terdapat lembaga-lembaga pendidikan sekolah yang terus dibangun. Ini berdampak pada banyaknya lembaga pendidikan sekolah, tetapi jumlah siswa tidak mendukung, dan kualitas pengajar maupun pengelolanya masih minim. Tercermin dari pernyataan Arnawita, A.md sebagai Operator Bidang Pendidikan Dasar:

"Sekolah-sekolah ada yang ditutup itu karena penduduknya pindah dan tidak ada siswa yang belajar di sekolah, jadi bukan siswa yang tidak mau disitu tetapi memang tidak ada lagi siswa. Strategi yang harus dilakukan agar sekolah tidak ditutup itu salah satunya adalah penduduknya harus banyak dan banyak anak-anak yang sekolah di sekolah tersebut"(wawancara, 13 Juli 2021).

Dari pernyataan tersebut kita dapat mengetahui jika sumber daya yang disalurkan terkategori tidak memberi manfaat sesuai dengan yang seharusnya. Oleh sebab itu, sosialisasi dan himbauan dalam perencanaan pembangunan haruslah didiskusikan lebih lanjut agar kuantitas dan kualitas dalam pelaksanaan program memberi manfaat yang 
lebih efektif dan efisien bagi pengembangan kualitas pendidikan.

Selain penjabaran berdasarkan indikator penelitian, penyebab masih rendahnya kualitas pendidikan di kabupaten aceh barat menurut masyarakat yaitu Nur Asma adalah rendahnya kesadaran diri untuk belajar secara mandiri, berikut pernyataannya:

"Sekarang ini anak-anak sekolah kebanyakan lalai dengan HP, kalau di suruh belajar baru dia belajar, kesadaran diri untuk belajar itu udah kurang. Setibanya orangtuanya acuh dengan anaknya, ya otomatis kualitas pendidikan anak itu menurun" (Wawancara, 14 Mei 2021)

Berdasarkan anggapan masyarakat tersebut, dapat dikatakan jika saat ini keberadaan teknologi seperti smathphone/HP menjadi sebab menurunnya minat dan kesadaran siswa untuk belajar yang berdampak pada penurunan kualitas pendidikan anak. Hal ini diperparah dengan temuan jika banyak orangtua yang terkadang tidak mengawasi pendidikan anaknya.

Upaya Pemerintah Kabupaten Aceh Barat dalam memperbaiki pendidikan terangkum dalam dalam misi pendidikan nasional (Pemerintah pusat, 2003) , yaitu:

a. Mengupayakan pemerataan dan perluasan akses dalam memperoleh pendidikan bermutu bagi penduduk Indonesia

b. Mengembangan potensi putra putri bangsa dengan penyediaan fasilitas demi menciptakan masyarakat belajar

c. Meningkatkan kesiapan masukan dan kualitas proses pendidikan guna mengoptimalkan pembentukan kepribadian yang bermoral

d. Meningkatkan akuntabilitas dan profesinalitas lembaga pendidikan sebab menjadi pusat pembuadayaan sikap dan nilai budaya, keterampilan serta ilmu pengetahuan menurut standar nasional dan global

e. Mengikutsertakan dan memberdayakan masyarakat dalam penyelenggaraan pendidikan berdasarkan konteks NKRI dan prinsip otonomi.

Berdasarkan visi dan misi pendidikan nasional, Dinas Pendidikan Kabupaten Aceh
Barat memiliki tugas dan fungsi untuk mengembangkan serta meningkattkan kemampuan siswa agar mampu menciptakan sumber daya manusia yang berkualitas dengan watak serta peradaban bermartabat dalam rangka mencerdaskan kehidupan bangsa. Selain itu, Dinas Pendidikan Kabupaten juga berperan mengembangkan kemampuan dan potensi siswa agar menjadi manusia yang bertaqwa kepada Tuhan Yang Maha Esa, memiliki ide kreatif, mandiri, demokratis serta utamanya dapat menjadi pribadi berilmu, dan bertanggungjawab, sehingga bisa memajukan daerah dan bangsanya sendiri.

Salah satu upaya Dinas Pendidikan untuk menyukseskan program peningkatan kualitas pendidikan adalah melakukan kerjasama maupun sosialisasi dengan akademisi, termasuk perguruan tinggi agar sama-sama bergerak mengatasi kendala dan masalah pendidikan yang ada di Aceh Barat. Sosialisasi yang dilakukan salah satunya ialah melibatkan mahasiswa Universitas Teuku Umar sebagai agen perbaikan pendidikan.

\section{Kendala Upaya Implementasi Kebijakan Peningkatan Kualitas Pendidikan}

Dalam merealisasikan kebijakan peningkatan kualitas pendidikan, pemerintah Aceh Barat dalam lingkup Dinas Pendidikan menyatakan ada tiga kendala utama yang menjadi penghambat yaitu:

a. Kendala sumber daya manusia

Kendala sumber daya manusia merupakan kendala paling utama yang dirasakan staf kedinasan. Penyelenggaraan kebijakan pendidikan masih menghadapi masalah akibat kurangnya kuantitas ataupun kualitas tenaga ahli dan pengajar di wilayah terpencil, sehingga kontribusi yang diharapkan dari kebijakan tidak dapat berjalan secara maksimal. Padahal kualitas SDM tenaga pendidik menjadi faktor kunci perbaikan kualitas pendidikan daerah terpencil (Khotimah et al., 2021).

b. Kendala anggaran

Kendala anggaran berupa keterbatasan anggaran dalam melaksanakan program peningkatan kualitas pendidikan, dimana anggaran telah banyak terpakai untuk memenuhi kebutuhan pegawai, baik itu gaji, tunjanan dan lain sebagainya, dengan alasan minimnya anggaran yang diterima Dinas 
Pendidikan Kabupaten. Hal ini kemudian mengakibatkan anggaran yang tersisa untuk program peningkatan kualitas pendidikan tidak lagi maksimal di lokasi penelitian.

Pihak dinas telah menjelaskan jika terdapat dana anggaran 20\% dari APBN (Anggaran Pendapatan Belanja Negara) untuk pendidikan, tetapi tidak semua dana tersebut dapat dialokasikan untuk program Dinas Pendidikan Kabupaten Aceh Barat.

c. Kendala lokasi

Kendala lokasi ini dialasankan pada masih terdapat daerah-daerah di Aceh Barat yang tergolong terpencil, sehingga di daerah tersebut jumlah tenaga pengajar, maupun pengelola lembaga pendidikan seperti sekolah masih sangat terbatas dengan kualitas yang sangat berbeda dibandingkan lembaga sekolah di perkotaan. Akibatnya, akses pendidikan yang di dapat juga tidak dapat menyeluruh. Realita ini sesuai dengan pandangan (Beatty et al., 2021) yaitu kesenjangan pendidikan berpengaruh besar pada kemampuan siswa jika berpegang pada standar kurikulum nasional.

Kabupaten Aceh Barat setidaknya memiliki 12 Kecamatan, dan ada beberapa kecamatan yang pendidikannya sulit diakses seperti yang dikatakan narasumber terletak di Desa Alu Kemang, Watak Barat, Watak Tim, Sungai Mas dan Pante Cereumen. Sebenarnya ada kebijakan pemerintah tentang bantuan guru bagi daerah terpencil, tetapi berdasarkan ulasan narasumber program tersebut belum terealisasikan secara baik dan maksimal.

\section{SIMPULAN}

Pemerintah Kabupaten Aceh Barat melalui Dinas Pendidikan telah melaksanakan implementasi kebijakan dalam meningkatkan kualitas pendidikan di Aceh Barat. Namun, implementasi yang dilakukan belum memberikan hasil maksimal. Mengacu pada Teori Edward III, dalam pelaksanaan kebijakan, Dinas Pendidikan Kabupaten Aceh Barat menghadapai masalah terkait kurangnya SDM seperti tenaga pengajar wilayah terpencil, dana bagi program-program yang akan di realisaiskan masih sangat terbatas. Struktur birokrasi kelembagaan pendidikan juga mengalami fragmentasi, dimana lembaga pendidikan yang dibangun sangat banyak, tetapi kelembagaannya tidak berperan secara maksimal untuk di pergunakan. Indikator disposisi juga menunjukkan sikap kerjasama dinas dan masyarakat masih tergolong minim dalam mensosialisasikan program kebijakan.

Solusi yang peneliti tawarkan ialah melakukan pemberdayaan/pelatihan bagi SDM di lembaga pendidikan, menjadikan aturan persebaran tenaga pengajar lebih tegas. Diharapkan Pemerintah lebih peka untuk memprioritaskan program kebijakan terlebih dahulu dalam penganggaran, serta dapat menyiapkan akses transportasi yang memudahkan tenaga pendidik menuju daerah terpencil dan menyediakan fasilitas berkualitas sesuai kebutuhan dari lembaga pendidikan.

\section{DAFTAR PUSTAKA}

Amin, K. (2018). Pengaruh Konflik Terhadap Pembangunan Pendidikan di Aceh. Nazhruna: Jurnal Pendidikan Islam, 1(2), 159-176.

BBC.com. (2019). Peringkat pendidikan Indonesia di Bawah Malaysia Dan Brunei, China Yang Terbaik Di Dunia. BBC NEWS INDONESIA.

BPS Kab Aceh Barat. (2021). Kabupaten Aceh Barat Dalam Angka. BPS Kabupaten Aceh Barat.

Budiharto, Triyono, \& Suparman. (2018). Literasi Sekolah Sebagai Upaya Penciptaan Masyarakat Pebelajar Yang Berdampak Pada Peningkatan Kualitas Pendidikan. Jurnal Ilmu-Ilmu Sejarah, Sosial, Budaya Dan Kependidikan, 5(1), 153-166.

Budiratna, H., \& Qibthiyyah, R. M. (2020). Evaluasi Atas Transfer Dana Otonomi Khusus Di Aceh, Papua, Dan Papua. Jurnal Indonesia Sosial Sains, 1(5), 402-414.

Creswell, J. W. (2010). Research Design Pendidikan Kualitatif, Kuantitatif, dan Mixed. Pustaka Pelajar.

Edward. III, G. C. (1980). Implementing Public Policy. Congresional, Quartely Press.

Fadhilah, \& Syahril. (2019). Peran Dinas Pendidikan Dalam Peningkatan Mutu Pendidikan. SERAMBI TABARAWI Jurnal Studi Pemikiran, Riset Dan Pengembangan Pendidikan Islam, 7(1), 109-128.

Inkiriwang, R. R. (2020). Kewajiban Negara Dalam Penyediaan Fasilitas Pendidikan Kepada Masyarakat Menurut Undang-Undang Nomor 20 Tahun 2003 Tentang Sistem Pendidkan Nasional. Lex Privatum, 8(2), 143-153.

Khotimah, H., Ilmiyah, L., \& Aryani, N. R. (2021). Problematika Pembelajaran Pai Di Daerah 
Nila Safrida, dkk, Implementasi Kebijakan Pemerintah dalam Meningkatkan Kualitas Pendidikan

Terpencil: Studi Atas Keterbatasan Sumber Daya Manusia. Tarbiyah Islamiyah, 11(1), 45-58.

Moleong, L. J. (2017). metode penelitian kualitatif. PT. Remaja.

Mulyadi, D. (2015). Studi Kebijakan Publik dan Pelayanan Publik. Alfabeta.

Pemerintah Pusat. (1949). Undang Undang Dasar 1945 Ri Pasal 31 Tentang Pendidikan Dan Kebudayaan Ayat 1 dan 3.

Pemerintah Pusat. (2021). Peraturan Pemerintah No 57 Tahun 2021 Tentang Standar Pendidikan Nasional.

Pemeritah Aceh. (2018). Qanun Aceh No 9 Tahun 2018 Tentang Penyelenggaraan Pendidikan Dayah.

Sagala, S. (2009). Manajemen Strategik Peningkatan Mutu Pendidikan (Bandung). Alfabeta.

Saputra, D., Syechalad, M. N., \& Nasir, M. (2015). Analisis Ketimpangan Pendidikan Terhadap Pertumbuhan Ekonomi Di Provinsi Aceh. Jurnal Ilmu Ekonomi Pascasarjana Universitas Syiah Kuala, 3(2), 1-9.

Suparno, \& Alfikar, G. (2019). Implementasi UUD NKRI 1945 Pasal 31 Ayat 1 Melalui Pengentasan Buta Aksara Program Nasional Pemberdayaan Masyarakat Generasi Sehat Dan Cerdas (Pnpm-Gsc) Terhadap Peningkatan Kesadaran Pendidikan Masyarakat Didesa Tawang Sari Kecamatan Sepauk Kabupaten Sintang. Jurnal PEKAN, 4(2), 159-167.

Syani, A. K., Mufid, S., \& Hazin, M. (2017). Komunikasi Dalam Implementasi Kebijakan Pendidikan Wajib Belajar 9 Tahun Di Kecamatan Ngadiluwih. Khazanah Pendidikan Jurnal Ilmiah Kependidikan, 11(1), 25-38.

Zairi, M. Bin. (2019). Pendidikan Aceh Peringkat 27 Secara Nasional, Salah Satu Penyebab Rendahnya Mutu Guru. Serambinews. Com. 